\title{
Serological and histological follow up of chronic hepatitis $\mathrm{B}$ infection
}

\author{
M RUIZ-MORENO, ${ }^{*}$ T CAMPS,${ }^{*} \mathrm{~J}$ G AGUADO,${ }^{*} \mathrm{~J}$ C PORRES,$\dagger$ H OLIVA, $\ddagger \mathrm{J}$ BARTOLOMÉ, $\dagger$ \\ AND V CARREÑO $\dagger$
}

Departments of ${ }^{*}$ Paediatrics, †Gastroenterology, and $¥$ Pathology, Fundación Jiménez Diaz, Madrid

SUMMARY In order to study the clinical, serological, and morphological evolution of chronic hepatitis B virus infection in childhood, a prospective study has been carried out. A total of 90 children with a chronic infection were followed up for a mean (SD) of $3(1.8)$ years. At the beginning of the study, 61 children were asymptomatic and 77 were household contacts of chronic carriers. Serologically 77 were hepatitis B e antigen ( $\mathrm{HBeAg}$ ) positive and 71 of them were positive to hepatitis $B$ virus DNA. The mean alanine aminotransferase activities were higher among $\mathrm{HBeAg}$ positive patients than in antihepatitis $\mathrm{B}$ e (anti-HBe) positive ones. The most severe histological damage was also found among $\mathrm{HBeAg}$ positive patients. The annual seroconversion rate was $14 \%$. A significant increase in the alanine aminotransferase activity was observed $13(5.6)$ months before appearance of anti-HBe in the $85 \%$ of cases. Among anti-HBe positive patients, the alanine aminotransferase activities were normal in all except three (19\%), two of whom had intrahepatic delta antigen. An increase in the histological activity was observed among patients who maintained $\mathrm{HBeAg}$ presence while an amelioration of liver damage was observed in anti-HBe carriers.

Chronic hepatitis B virus infection has two distinguishable phases. During the first phase there are circulating Dane particles, hepatitis $\mathrm{B}$ e antigen $(\mathrm{HBe} \mathrm{Ag})$ and hepatitis B virus DNA (HBV-DNA). Usually there is biochemical or pathological evidence of disease activity, or both. Later, either spontaneously or with antiviral treatment, those particles disappear from the circulation, $\mathrm{HBeAg}$ and HBV-DNA become undetectable, and antihepatitis $B$ e (anti-HBe) develops. ${ }^{1}$

Several reports on the natural history of chronic hepatitis B infection in children have been published with differing results. ${ }^{2-8}$ Cirrhosis has been reported in $3 \%{ }^{7}$ to $25 \% .^{4}$ Because of these varying findings we have carried out a prospective study in children with chronic hepatitis B virus infection.

\section{Patients and methods}

Our study comprised 134 children who were positive carriers for hepatitis B and who attended our hospital from 1979 to $1986 ; 44$ were not available for long term follow up. We studied the remaining 90 children: all were hepatitis $B$ surface antigen (HBsAg) and antihepatitis B c (anti-HBc) positive with raised alanine aminotransferase activities for at least six months and were available for long term follow up. Other causes of liver disease were ruled out $\left(\alpha_{1}\right.$ antitrypsin deficiency, Wilson's disease, autoimmune chronic hepatitis, etc). The clinical, serological, and biochemical features are summarised in table 1 . The children ranged from 6 months to 14 years of age (mean (SD) 6 (3) years). There were 55 boys and 35 girls. A clinical and serological follow up (every four months) was performed during a mean of three years (range six months to seven years). At the beginning of the study, $29(32 \%)$ children had one or more of the following clinical symptoms of liver disease: asthenia $(n=14,15 \%)$, anorexia $(n=11,12 \%)$, cholestasis $(n=10,11 \%)$, abdominal pain $(n=9$, $10 \%)$, vomiting $(n=7,8 \%)$, and fever $(n=5,6 \%)$; the other 61 children were symptomless. Details of results of investigations for serology of $\mathrm{HBeAg}$ and anti- $\mathrm{HBe}$, activity of alanine aminotransferase, and liver histology are shown in table 2 . Of the symptomatic patients, $24(83 \%)$ had hepatomegaly and three $(10 \%)$ splenomegaly compared with four $(6 \%)$ and none, respectively in the asymptomatic ones. In 77 children the infection was acquired by 
1166 Ruiz-Moreno, Camps, Aguado, Porres, Oliva, Bartolomé, and Carreño

Table 1 Baseline clinical and serological features of children studied $(n=90)$

\begin{tabular}{|c|c|c|c|c|c|}
\hline & \multicolumn{5}{|c|}{ Serological markers } \\
\hline & $\begin{array}{l}\text { HbeAg+ } \\
H B V-D N A+ \\
H B V-D N A p+\end{array}$ & $\begin{array}{l}\text { HbeAg+ } \\
H B V-D N A+ \\
H B V-D N A p-\end{array}$ & $\begin{array}{l}\text { HbeAg+ } \\
H B V-D N A- \\
H B V-D N A p-\end{array}$ & Anti-HBe+ & $\begin{array}{l}\text { Anti-HBe+ } \\
\text { Anti-HD+ }\end{array}$ \\
\hline No $(\%)$ of children & $67(74)$ & $4(4)$ & $6(7)$ & $11(12)$ & $2(2)$ \\
\hline Male/female & $44 / 23$ & $2 / 2$ & $2 / 4$ & $6 / 5$ & $1 / 1$ \\
\hline Mean (SD) age (years) & $6 \cdot 0(3 \cdot 0)$ & $6 \cdot 1(6 \cdot 0)$ & $6 \cdot 2(1 \cdot 7)$ & $6 \cdot 4(3 \cdot 3)$ & $4 \cdot 7(0.4)$ \\
\hline \multicolumn{6}{|l|}{ Mean (SD) alanine } \\
\hline aminotransferase (IU/l) & $232(289)$ & $293(218)$ & $147(148)$ & $37(14)$ & $87(40)$ \\
\hline No (\%) with symptoms & $17(25)$ & $2(50)$ & $1(17)$ & $7(64)$ & $2(100)$ \\
\hline No (\%) with hepatomegaly & $21(31)$ & $1(25)$ & $1(17)$ & $3(27)$ & $2(100)$ \\
\hline
\end{tabular}

HBV-DNAp=hepatitis B virus DNA polymerase.

Table 2 Basal features of symptomatic and asymptomatic patients

\begin{tabular}{lcc}
\hline & $\begin{array}{l}\text { Asymptomatic } \\
\text { patients } \\
(n=61)\end{array}$ & $\begin{array}{l}\text { Symptomatic } \\
\text { patients } \\
(n=29)\end{array}$ \\
\hline $\begin{array}{l}\text { No (\%) HBeAg positive } \\
\text { No (\%) anti-HBe positive } \\
\text { Mean (SD) alanine } \\
\text { aminotransferase (IU/l) }\end{array}$ & $\begin{array}{c}57(93) \\
4(7)\end{array}$ & $20(69)$ \\
$\begin{array}{l}\text { No (\%) with diagnosis } \\
\text { from histology of: }\end{array}$ & $210(273)$ & $183(254)$ \\
$\quad \begin{array}{l}\text { Chronic active hepatitis } \\
\text { Chronic persistent } \\
\text { hepatitis }\end{array}$ & $39(79)$ & $17(59)$ \\
$\quad \begin{array}{l}\text { Cirrhosis } \\
\text { Minimal changes }\end{array}$ & $1(2)$ & $9(31)$ \\
\hline
\end{tabular}

household contact. Two children had a previous transfusion, and in 11 children the cause of the infection was unknown.

Serology for the presence of markers for hepatitis B virus, anti-HIV, antihepatitis delta (anti-HD), and liver function tests were performed every four months using standard methods (Abbott commercial assays and SMAC Technicon). HBV-DNA was tested by dot-blot hybridisation, using a HBV-DNA probe isolated from the $\mathrm{pBH} 20-\mathrm{HBV}$ plasmid. The specific activity of the ${ }^{32} \mathrm{P}-\mathrm{HBV}-\mathrm{DNA}$ after nicktranslation was $7 \times 10^{7}-3 \times 10^{8} \mathrm{cpm} / \mu \mathrm{g}$ DNA. This technique detected less than $0.5 \mathrm{pg}$ of HBV-DNA.

At the beginning of the study a liver biopsy was performed under general anaesthesia in 78 of the 90 children using a Tru-Cut needle. A second liver biopsy was performed during a mean follow up of three years (range from eight months to seven years) in 27 children. The presence of liver HDAg among anti-HD positive patients was detected by immunoperoxidase staining using a conjugated anti-HD antibody (anti-HD titre: 1/1000). Liver HBsAg and hepatitis B core antigen ( $\mathrm{HBcAg})$ were also tested by immunoperoxidase technique (Dakopatts a/s).

\section{Results}

In relation to the ' $\mathrm{e}$ ' system, 77 children were $\mathrm{HBeAg}$ positive and 13 had anti-HBe. A total of 71 of the $\mathrm{HBeAg}$ positive children had circulating HBV-DNA. HBeAg positive patients had a significantly higher mean (SD) initial alanine aminotransferase activity than those with anti-HBe $(232$ (289) compared with 37 (14) IU/1). During follow up 24 became negative for HBeAg and HBV-DNA and 21 developed anti-HBe. The time from the beginning of the study until the seroconversion to anti-HBe varied from six months to five $(2.3(1.4))$ years. The annual seroconversion rate was $14 \%$. None of the anti-HBe children had HBV-DNA, although two were anti-HD positive.

At the end of the study all the children were clinically asymptomatic. With respect to the physical signs the frequency of hepatomegaly increased in the children who remained with $\mathrm{HBeAg}$ (basal 13 (24\%) compared with final $31(58 \%))$, while a decrease was observed in children who seroconverted to anti-HBe (basal $10(47 \%)$ compared with final three $(14 \%))$. No changes were observed in the anti$\mathrm{HBe}$ children (basal five (38\%) compared with final two (15\%)).

Among the 21 children who seroconverted to anti$\mathrm{HBe}$, an increase of at least three times the basal alanine aminotransferase value (18 (12) times the normal value) before seroconversion was observed in 18 cases $(85 \%)$. The time between the alanine aminotransferase peak and the appearance of antiHBe was $13(5 \cdot 6)$ months (range: 6-28 months). These alanine aminotransferase peaks were similar to those found in acute hepatitis, although the children did not suffer any symptom or clinical complication. All the children who seroconverted to anti-HBe had normal alanine aminotransferase by 
$4 \cdot 3(5 \cdot 8)$ months (range: $0-17$ months) and remained so during the follow up (two years). Eight children who were anti-HBe positive initially had normal alanine aminotransferase activities. Two children returned to normal in 12 months but three remained abnormal in follow up periods of 38 to 72 months. Two of the latter had anti-HD in serum and HDAg in the liver biopsy specimen.

A basal liver biopsy was performed on 68 of the 71 children with viral replication markers $(\mathrm{HBeAg}$, HBV-DNA). Although most of the children $(n=54)$ had a chronic active hepatitis, 11 had a chronic persistent hepatitis, two had liver active cirrhosis, and one had minimal changes. After the beginning of the study, a second liver biopsy was obtained in 24 children. Of the 17 who remained positive to $\mathrm{HBeAg}$, the histological picture was the same in nine cases. The other eight children showed a worsening of the histological lesion (table 3). All 17

Table 3 Histological evolution of chronic hepatitis $B$ in children

\begin{tabular}{|c|c|c|}
\hline & \multicolumn{2}{|l|}{ Liver biopsy } \\
\hline & Basal & Final \\
\hline \multicolumn{3}{|l|}{$\begin{array}{l}\text { No }(\%) \text { children who } \\
\text { remained } \mathrm{HBeAg} \\
\text { positive during } \\
\text { the study }(\mathrm{n}=17):^{*} \\
\text { Chronic active }\end{array}$} \\
\hline hepatitis & $\begin{array}{l}10(59) \\
(9 \text { mild, } \\
1 \text { moderate })\end{array}$ & $\begin{array}{l}11(65) \\
(7 \text { mild, } \\
4 \text { moderate })\end{array}$ \\
\hline $\begin{array}{l}\text { Chronic persistent } \\
\text { hepatitis } \\
\text { Active cirrhosis }\end{array}$ & $\begin{array}{l}6(35) \\
1(6)\end{array}$ & $\begin{array}{l}3(18) \\
3(18)\end{array}$ \\
\hline \multicolumn{3}{|l|}{$\begin{array}{l}\text { No }(\%) \text { children who } \\
\text { seroconverted from } \\
\text { HBeAg to } \\
\text { anti-HBe }(n=7): \dagger \\
\text { Chronic active }\end{array}$} \\
\hline $\begin{array}{l}\text { Chronic active } \\
\text { hepatitis } \\
\text { Chronic peristent } \\
\text { hepatitis }\end{array}$ & $5(72)$ & $4(57)$ \\
\hline Minimal changes & - & $3(43)$ \\
\hline \multicolumn{3}{|l|}{$\begin{array}{l}\text { No }(\%) \text { children who } \\
\text { remained anti-Hbe } \\
\text { positive }(n=3): \ddagger \\
\text { Chronic active }\end{array}$} \\
\hline hepatitis & $\begin{array}{l}2(67)(\mathrm{HDAg}+) \\
(1 \text { mild, } \\
1 \text { moderate })\end{array}$ & $\begin{array}{c}2(67)(\mathrm{HDAg}+) \\
(2 \text { moderate })\end{array}$ \\
\hline $\begin{array}{l}\text { Chronic persistent } \\
\text { hepatitis }\end{array}$ & $1(33)$ & - \\
\hline Minimal changes & - & $1(33)$ \\
\hline
\end{tabular}

Mean (SD) time between basal and final liver biopsies: *2.7 (1.5) years; $\dagger 3.8(0.8)$ years; and $\ddagger 4 \cdot 1(0.6)$ years. children remained positive to liver $\mathrm{HBsAg}$ and HBcAg, most of them (15/17) showed a diffuse pattern of $\mathrm{HBcAg}$.

A second liver biopsy was also performed on seven children who seroconverted to anti-HBe during the three and five year periods (mean 3.8 $(0.8)$ years). Five cases showed an improvement in the histology and in two cases the same liver lesion was observed. The basal liver biopsy specimen in these seven children was positive to $\mathrm{HBsAg}$ and HBcAg. In the second biopsy specimen, however, $\mathrm{HBcAg}$ was negative in all these cases and $\mathrm{HBsAg}$ remained positive. All but one had a predominantly focal pattern of $\mathrm{HBcAg}$ in the liver cell. The study of the $\mathrm{HBsAg}$ and $\mathrm{HBcAg}$ expression in the rest of the patients who had a liver biopsy was not available.

The basal histology of the 10 anti-HBe positive patients was two with chronic active hepatitis, six with chronic persistent hepatitis, one with inactive cirrhosis, and one with minimal changes. The liver histology from the second biopsy specimen obtained in the three anti-HBe children who remained with an abnormal alanine aminotransferase activity, resulted in the same histological findings in two cases (HDAg positive). In the HDAg negative patåent, an amelioration of the histological lesion was observed.

\section{Discussion}

In our experience children with hepatitis B virus replication markers suffered a more active liver disease biochemically and histologically than those without replication. These results are in accordance with previous reports. ${ }^{78}$ Although at the end of the study all the children were asymptomatic, in those who seroconverted to anti-HBe a decrease in the frequency of hepatomegaly was observed, with an important histological improvement. In contrast, children who remained $\mathrm{HBeAg}$ positive had an increase in the frequency of hepatomegaly and a progression of the histological lesion (in some cases to liver active cirrhosis). This result is lower than those reported by other authors, ${ }^{45}$ and different from that of Bortolotti et al who did not find progression to cirrhosis. ${ }^{27} \mathrm{~A}$ possible explanation could be the technical differences in the performance of the liver biopsies. Dupuy et al obtained the biopsy specimens under laparoscope control, ${ }^{4}$ which could increase the probability of a diagnosis of cirrhosis. ${ }^{8}$ We used a blind biopsy technique with a Tru-Cut rather than a Menghini needle, as was used by Bortolotti et al. ${ }^{7}$ Therefore, laparoscope and the longer cylinder obtained with our needle will most likely account for the differences.

Additionally, our data differ from that of Lai et 
al. ${ }^{9}$ Our children with hepatitis B virus replication markers had an abnormal alanine aminotransferase activity, while most of their Chinese children had normal activities. This variation could be explained by racial and epidemiological differences. Chinese children acquired the infection at birth, while ours did not. The interferon concentrations in lymphocytes of Chinese people are normal but are abnormal in white races. ${ }^{10}$

All the children from our study who seroconverted remained $\mathrm{HBsAg}$ positive; this is in accordance with previous studies. ${ }^{6} 8$ Thus the risk of the development of hepatoma probably persists in these children. ${ }^{11}$ Further studies are required to indicate if HBV-DNA remains in an integrated form after seroconversion.

The children with persistent viral replication had a diffuse pattern of $\mathrm{HBcAg}$ in the liver. In contrast, those children who seroconverted to anti-HBe showed a focal pattern. These results agree with those of Bortolotti et al, ${ }^{12}$ and so testing for $\mathrm{HBcAg}$ in the liver could be useful as a prognosis indicator.

During seroconversion, an increase in alanine aminotransferase activity similar to that in acute hepatitis was observed in most of the children. In our experience, however, only $50 \%$ of the adults who seroconverted had a previous alanine aminotransferase increase. ${ }^{13}$ Although we are unsure as to the reason for this difference between adults and children from the same population, a possible explanation is the difference in their immune systems. In support of this theory, we observed an important regression of liver disease in adults during seroconversion while none was detected in the children. ${ }^{14}$ This variation could be due to the fact that liver cirrhosis is less common in children, or also that they regenerate the liver cells more quickly than adults.

With the exception of two patients with delta superinfection, all the children with anti-HBe and abnormal alanine aminotransferase activity at the beginning of the study had normal alanine aminotransferase at the end of the follow up period. Therefore, the anti-HBe status in children correlated with a normal alanine aminotransferase activity and good prognosis in the absence of the delta virus. During the follow up reactivation of viral replication in the anti-HBe children did not take place as all the children remained HBV-DNA negative in contrast with that reported in adults. ${ }^{15}$ A similar lack of HBV-DNA among anti-HBe children has been reported. ${ }^{25}$ This suggests that clearance of all HBV-DNA replicative forms in hepatocytes occurred in these children. In adults, however, HBV-DNA supercoiled could remain in hepatocytes due to the lack of elimination and consequently reactivation takes place in about $40 \%$ of anti-HBe cases (unpublished data).

This study confirms the high frequency of advanced liver disease in association with chronic hepatitis B virus infection and a persistently raised serum transaminase activity for a period of more than six months. Such patients should be considered for treatment with antiviral agents both to limit progression of liver disease and to reduce the risks of HBV-DNA integration and the subsequent development of hepatoma. ${ }^{16}{ }^{17}$ In such a case, if the treatment is efficient, the prognosis of the disease will be more favourable. ${ }^{18}$

JB was supported by a grant from the Fondo de Investigaciones Sanitarias de la Seguridad Social, Insalud.

\section{References}

1 Nordentfelt E, Kjellen L. Dane particles, DNA polymerase and e antigen in two distinct categories of hepatitis $B$ antigen carriers. Intervirology 1975;5:225-32.

2 Bortolotti F, Cadrobbi P, Rugge M, Pontisso P, Armigliato M, Realdi G. Evolution of chronic hepatitis $B$ of children towards a 'healthy' HBsAg carrier state: results a prospective study. J Hepatol 1986;3:S35.

3 Bortolotti F, Cadrobbi P, Crivellaro C, Bertaggia A, Alberti A, Realdi G. Chronic hepatitis type B in childhood: longitudinal study of 35 cases. Gut 1981;22:499-504.

4 Dupuy JM, Kostewitz E, Alagille D. Hepatitis B in children. $J$ Pediatr 1978;98:17-20.

5 Codoñer P, Scotto J, Hadchouel M, Bernard O, Alagille D. Evolution des hepatites chroniques liées au virus $B$ chez l'enfant. Etude de l'ADN viral sérique. Gastroenterol Clin Biol 1985;9:516-21.

6 Bortolotti F, Cadrobbi P, Crivellaro C, et al. Changes in hepatitis $\mathrm{Be}$ antigen/antibody system in children with chronic hepatitis B virus infection. J Pediatr 1983;103:718-22.

${ }^{7}$ Bortolotti F, Calzia R, Cadrobbi P, et al. Liver cirrhosis associated with chronic hepatitis $B$ virus infection in childhood. J Pediatr 1986;108:224-7.

${ }^{8}$ Codoñer P, Brines J, Bernard O, Hadchouel M, Alagille D, Scotto $\mathbf{J}$. ADN serico del virus $\mathbf{B}$ de la hepatitis en niños con infeccion crónica. An Esp Pediatr 1986;26:98-104.

9 Lai CL, Lin HJ, Yeoh EK, Lok AS, Wu PC, Yeung CY. Placebo-controlled trial of recombinant $\alpha_{2}$-interferon in chinese HBsAg carrier children. Lancet 1987;ii:877-80.

10 Kato Y, Nakagawa H, Kobayashi K, Hattori N, Hatano K. Interferon production by peripheral lymphocytes in $\mathrm{HBs} \mathrm{Ag}$ positive liver disease. Hepatology 1982;2:789-90.

11 Kew MC. The possible etiologic role of hepatitis B virus in hepatocellular carcinoma: evidence from Southern Africa. In: Chisari, ed. Advances in hepatitis research. New York: Masson, 1984:203-15.

12 Bortolotti F, Alberti A, Cadrobbi P, Rugge M, Armigliato M, Realdi G. Prognostic value of hepatitis B core antigen ( $\mathrm{HBcAg}$ ) expression in the liver of children with chronic hepatitis type $B$. Liver 1985;5:40-7.

13 Porres JC, Carreño V, Mora I, et al. Different doses of recombinant interferon alpha in the treatment of chronic hepatitis B patients without antibodies against the human immunodeficiency virus. Hepatogastroenterology 1988;35: 300-3.

14 Carreño V, Porres JC, Mora I, et al. Prolonged (6 months) treatment of chronic hepatitis $B$ virus infection with recombinant leukocyte A interferon. Liver 1987;7:325-32.

15 Perrillo RP, Campbell CR, Sanders GE, Regenstein FG, Bodicky CJ. Spontaneous clearance and reactivation of hepatitis 
B virus infection among homosexuals with chronic type B hepatitis. Ann Intern Med 1984;100:43-6.

16 Perrillo RP. Anti-viral therapy of chronic viral hepatitis. Current Opinion in Gastroenterology 1988;4:420-7.

17 Perrillo RP, Regenstein FG, Peters NG, et al. Prednisolone withdrawal followed by recombinant alpha interferon. Treatment of chronic hepatitis B. A randomised control trial. Ann Intern Med 1988;109:95-100.

18 la Banda F, Ruiz M, Carreño V, et al. Recombinant $\alpha_{2^{-}}$ interferon treatment in children with chronic hepatitis B. Lancet $1988 ; i: 250$.

Correspondence to Dr V Carreño, Department of Gastroenterology, Fundación Jiménez Diaz, Avenida Reyes Catolicos 2, 28040 Madrid, Spain.

Accepted 16 March 1989 